\title{
Review of Research on Credit Risk Management for Rural Credit Cooperatives*
}

\author{
Xin Song ${ }^{1}, \mathrm{Li} \mathrm{Li}^{1 \dagger}$, Lei Xiao ${ }^{2}$ \\ ${ }^{1}$ Pan-Asia Business School, Yunnan Normal University, 650092 Kunming, China, \\ Email:1593666405@qq.com,43063010@qq.com \\ ${ }^{2}$ School of MARXISM Studies, Kunming University, 650214 Kunming, China; \\ Email:391644664@qq.com
}

Received 29 December 2016

Accepted 22 January 2017

\begin{abstract}
With the rapid development of rural micro-credit, whether the "agriculture, rural areas and farmers" problems have been effectively solved, whether the credit risk has been effectively controlled, these have become the focus of our attention to the rural economic environment. The main content of this paper contains four aspects: the classification and characteristics of credit risk, the problems and factors of credit risk, the model and evaluation of credit risk, the countermeasures and suggestions of credit risk. This paper reviews the research of credit risk management for rural credit cooperatives from the above four aspects, and makes a brief summary.
\end{abstract}

Keywords: Rural credit cooperatives, Credit risk, Research review

\section{Introduction}

Since the popularizing of rural credit cooperatives in China after 2000, the development of rural credit cooperatives in China has achieved a leap. Especially in rural areas, the role of financial services for farmers is obvious. Rural credit cooperatives have become major financial institutions of credit for farmers. In recent years, rural areas, agriculture and farmers issues have become the focus of rural economic development. Because rural credit cooperatives play a most important role in Chinese rural financial environment, their credit risk has also become the important question in rural economic research.

Relating to the personal financial services of rural credit cooperatives in China, credit business mainly includes rural household micro-credit loans and farmers group guaranteed loans. And micro-credit for farmers occupies the dominant position in credit business. Rural household micro-credit loans are micro-credit loans that rural credit cooperatives issued to farmers for agricultural production and consumption, within the approved quota and time limit based on the credit reputation, assets and repayment ability of farmers. At present, rural household micro-credit has become one of the main ways to obtain credit loans in rural areas of China, which plays an important role in accelerating rural economic development, improving agricultural structure and promoting the coordinated development of urban and rural areas.

On the research of farmers' credit risk, foreign scholars began earlier (70s), domestic scholars began late $(90 \mathrm{~s})$. This paper reviewed the research based on the domestic and foreign credit risk in recent years, and this paper is divided into four parts: the classification and characteristics of credit risk, the problems and

*Corresponding author: Li Li, Pan-Asia Business School, Yunnan Normal University, Kunming, China. Email:43063010@qq.com.

${ }^{\dagger}$ Address: No. 298, 121 Street, Wuhua District, Kunming 650092, China 
factors of credit risk, the model and evaluation of credit risk, the countermeasures and suggestions of credit risk. We will give a more comprehensive analysis of the current situation of credit risk in rural credit cooperatives, and make comments and conclusions.

\section{The classification and characteristics of credit risk}

\subsection{The types of credit risks in rural credit cooperatives}

Credit risk refers to the fact that the borrower cannot return the credit principal and interest for various reasons on time, which makes the actual income result deviate from the expected profit goal and suffer the loss of assets in the operation and management of the rural credit cooperatives. Domestic scholars study earlier on the type of credit risk, can be divided into five categories, including moral hazard, credit risk, operational risk, management risk and natural risk. Huang Jian (2003) [1] points that the potential risks of micro-credit farmers cannot be ignored, destroys the rural economic environment, risk mainly credit risk, operational risk, management risk and market risk four aspects. Wu Baoshan (2006) argues that the main forms of rural credit risk are operational risk, management risk, local policy risk, farmer credit risk and loan transfer risk. Dai Lixin (2008) [2] divides credit risk into natural risk, borrower's risk, debtor's risk and government's risk by using 30 rural credit cooperatives and two banking regulatory bureaus in five districts of BD. Zhu Xinle (2010) [3] takes Jilin Province rural credit cooperatives as an example to study the risk types of rural micro-credit, the main risk is credit risk, operational risk and natural risk. Based on the survey data of rural microfinance companies in Jiangsu Province, Tan Zhongming (2011) [4] finds that there are many risks in rural microfinance companies, including legal risk, credit risk, operational risk, liquidity risk and regulatory risk.

In summary, although most scholars put the credit risk into five categories, but the credit level of rural credit cooperatives and farmers, natural risk and market risk are the objective factors, rural financial institutions face is mainly from the farmers' credit risk. When the farmer defaults on the small loan, the unsecured microloan is just relying on Farmers' credit guarantee to repay the loan, there is a great deal of uncertainty.

\subsection{Characteristics of credit risk in rural credit cooperatives}

Generally speaking, credit risk of rural credit cooperatives has three main characteristics. The first is objectivity, as long as there is credit activities, credit risk will not be transferred based on people's will and objective existence. It can be said, as long as the market economy, credit risk is inevitable. The second is spreading, the loss of funds caused by credit risk that not only affect the survival and development of rural credit cooperatives, more is caused by the associated chain reflected. The third is controllable, the rural credit cooperatives in accordance with certain methods and system can advance the credit risk identification, prediction, prevention and post resolve the matter, and the risk can be minimized by controlling.

\section{Problems and factors for credit risk}

\subsection{Information asymmetry between borrowers and lenders}

Duan Wenjie (2009) [5] from the farmers point of view, that farmers in order to obtain loans, will inevitably hide their own negative information, coupled with staff negligence, rural credit rating is not necessarily reliable, leading to loans to non-trustworthy farmers, resulting in moral hazard. Zeng Zhiming (2010) [6] from the information asymmetry theory, believes that the credit sides often cannot have enough information, cannot make accurate judgments, which affect both the transaction behavior and market efficiency. In this case, farmers become a party with information advantage, resulting in moral hazard and adverse selection. Sheng Guanghua (2014) [7] argues that rural credit cooperatives cannot fully grasp the actual situation of farmer loan projects because of information asymmetry. Therefore, from the farmer's point of view, the expected return of observing contracts are less than expected return of not complying with the contract. So the dominant strategy is farmers choose not to comply with the contract.

\subsection{Imperfect pre examination mechanism of rural credit cooperatives}

Pre examination of the relevant qualifications of farmers is a prerequisite for the signing of the loan contract, but also an essential program of borrowing behavior. The 
significance of the review is to assess the size of the loan risk, and thus determine the success of the loan transaction. Yang Xisun (2007) [8] believes that rural credit cooperatives lack of perfect credit system, a number of rural credit cooperatives in the credit rating of the farmers when only to see whether the credit situation of the farmers early, there is no complete economic household files data. Zeng Zhiming (2010) finds that personal information storage is only farmers basic information and loan repayment information through the investigation of Hunan rural credit cooperatives. Such as product quality, household and personal gains and losses default status are not complete collected, lack of query service. Tan Zhongming (2011) believes that the internal restraint mechanism of rural credit cooperatives is not perfect, the operational process becomes a mere formality, business inspection is mainly checked by credit workers, and risk awareness is very weak.

\subsection{Lower risk management level of rural credit cooperatives}

Compared with the commercial financial institutions, Huang Boyong (2008) [9] argues that both hardware and staff quality are at a low level. In the identification, prevention of financial risks and innovative financial products, are obviously inadequate. Zhu Xinle (2010) believes that rural credit cooperatives, savings banks and other rural financial institutions in the large range of outlets, the good and bad personnel qualities are intermingled, the work hard avoids negligence and mistake.

\subsection{Other factors}

Chavan P (2002) [10] reviews the empirical evidence of NGO-led micro-credit schemes in several developing countries and compared it with the Indian Rural Credit Relief Program, which concludes that the practice of Grameen Bank creditors in Bangladesh has led to the credit debt cycle. Cipollini (2012) [11] studies the factors that affect the credit risk of European commercial banks, including liquidity and credit risk, asset size, income diversification and market power. Jansson KH (2013) [12] presents and compares institutional frameworks for agricultural credit markets in selected European countries, conducts risk assessments of agricultural credit markets based on questionnaires of selected agricultural financial experts, finds that the most common reasons for refusing the loan applications are related to economic performance and the situation of farmers .Li Zhengbo (2006) [13] uses the logit model to analyze the sample survey data of Shandong, Shanxi and Shaanxi provinces, and finds that age and educational level have a positive effect on the farmers' default. But the expenditure structure and income structure of peasant households will affect the farmers' default probability. In addition, the loan interest rate and loan term have an obvious impact on the probability of default. The higher the loan interest rate is, the shorter the loan term is, and the more likely the farmer defaults. Wei Lan (2013) [14] through the survey data of 300 rural households in Liaoning Province, to establish logistic regression model to identify the default farmers, believes that the number of family labor, farm income, total household assets, the use of the loans with peasant household credit risk is negatively related; family population, cultivated land area, household expenditures, the amount of loans with credit risk is positively related.

\section{Model and Evaluation of credit risk}

For the evaluation of credit risk, foreign scholars mostly evaluate the credit rating or credit score of the company or institution, or calculate the default probability of the large commercial banks to manage the risk. For the evaluation of farmers and individuals, foreign scholars from developed countries have studied less. Cipollini and Fiordelisi (2012) takes the panel probit regression model to establish the credit risk score model by using the stable covariance matrix. Malik (2012) [15] applies the data of a UK bank credit card portfolio to construct a Markov chain behavior score model, incorporating economic variables and loan terms, to establish an investment portfolio in credit risk consumer loans for corporate credit risk research. Dadson Awunyo-Vitor (2014) [16] uses descriptive statistics, variance analysis (ANOVA) and Heckman's two-stage regression model to determine the factors affecting agricultural credit rationing on data from 595 households in the Brong Ahafo district of Ghana.

On the contrary, the study of domestic scholars is more in-depth. In the aspect of system analysis and grading, analytic hierarchy process (AHP), Delphi method and fuzzy mathematics method are more primitive, but these methods have too much subjective factor to determine the weight of the index, so credit 
evaluation of farmers is difficult to be objective and impartial. $\mathrm{Hu} \mathrm{Yu} \mathrm{(2007)} \mathrm{[17]} \mathrm{uses} \mathrm{uncertain} \mathrm{type} \mathrm{of}$ analytic hierarchy process (UTAHP) to determine the weight of indicators, which reduces the subjective degree of each index weight, and he divides the index system of farmer credit rating into four categories according to different attributes: family structural characteristics, solvency, business conditions, the credibility of the situation. Nie Yong (2009) [18] applies the multi-objective decision analysis method to the performance evaluation of farmers' micro-credit, and can scientifically evaluate the comprehensive benefits of farmers' micro-credit. Wang Jing (2011) [19] attempts to use the mutation evaluation method to classify three types of mutation system, including cusp mutation, dovetail mutation and butterfly mutation. This method not only reduces the subjectivity of multiobjective analysis when determining factors of index weight but also absorb the advantages of the method of fuzzy mathematics and analytic hierarchy process (AHP).Finally, the sample data of rural credit cooperatives in Yangling of Shaanxi Province are used to carry out an empirical study, which verifies the objective and rationality of the method.

In addition, Yao Shuqiong (2012) [20] by empirical analysis of survey data of agriculture, rural areas and farmers credit cooperatives in Yangling District of Shaanxi Province, the index variables were normality test, variance test and multicollinearity test, and establishes credit evaluation model of BP neural network. The results show that the overall accuracy of the model is $100 \%$ for the training samples, and $90 \%$ for the default samples of the test.Hu Haiqing (2012) [21] uses 151 small and medium enterprise sample data for empirical analysis, and constructs credit evaluation model based on SVM and BP neural network. The results show that classification accuracy of SVM model is significantly higher than BP neural network model. Chi Guotai (2015) [22] uses a complex comprehensive discriminate analysis to empirically study 2044households of large-scale commercial banks in China, the results show that education and Engel coefficient is a key indicator to distinguish farmers' default. And he demonstrates that the farmer loans of the CCC level can achieve the target profit of the bank and the farmer loans of $\mathrm{CC}$ level above can achieve the breakeven of the bank.

\section{Countermeasures and suggestions of credit risk}

\subsection{Establish a guarantee system}

The credit business of rural credit cooperatives, especially micro-credit, is uncovered and unsecured, which is the root cause of credit risk. The Basel Accord also points out that the guarantee is the necessary tool to mitigate the credit risk. The establishment of group cooperation guarantee system, on the one hand, farmers can reduce the asymmetry of information with the lending institutions; on the other hand, group cooperation can obtain a larger amount of loans to alleviate the difficulty of the loans to farmers and the problem of low amount. Xiong Xueping (2005) [23] analyzes the GB model in Bangladesh, and concludes that the system of farmer household guarantee and group center meeting system is a strong system guarantee for credit risk, which can be energetically implemented in densely populated areas. However, based on sample survey of 113 farmers' cooperative economic organizations in Guangxi Province, Yang Xisun (2007) [8] finds that Chinese implementation of group guarantee system is difficult. There are three reasons: the first is the trust between members of the group is difficult to estimate; the second is the group of farmers between the demand for loans and loan demand time cannot reach agreement; the third is implementation of the responsibility for breach of contract is not clear, the principal repayment of default is ambiguous. Starting from the dual structure of the rural financial supply, Han Xiping (2014) [24] fully understands the connotation and the boundary of the form of security, to build a "dual structure, four levels, $n$ form" credit guarantee system.

\subsection{Improve the internal management mechanism of rural credit cooperatives}

From the perspective of self-construction of rural credit cooperatives, Ding Yezhen (2006) [25] believes that credit institutions in rural credit cooperatives should strengthen staff training, improve the quality of staff, and establish employee incentive mechanism to reduce the credit risk. Based on the credit control system, Yang Hongli (2009) [26] increases the macroeconomic information and agricultural information to establish early warning system and the buffer system of credit risk, which improves internal risk prevention and 
control organizations of rural credit cooperatives and forms effective self-discipline mechanism. Ma Xiaonan (2013) [27] believes that the difficulty of credit risk control of rural credit cooperatives is the inherent risk of internal management mechanism. Rural credit cooperatives should strengthen the reform of corporate governance structure to improve the property rights system of rural credit cooperatives, to achieve the interests to match the responsibilities of borrowers and lenders. Tong Yuanbao (2014) [28] studies the farmer credit risk in Hainan Province and finds that the rural credit cooperatives in Hainan Province innovatively uses the "four-deliver" mechanism and "integrity Award" system to encourage farmers to accumulate good credit records.

\subsection{Other factors}

Agriculture is a basic industry, relating to the livelihood of the farmers, agriculture with the characteristics of natural risk makes it more important to strengthen the construction of agricultural insurance system. The implementation of the agricultural insurance system, exploration of rural credit cooperatives and agricultural insurance cooperation mechanism, are conducive to improve the tolerance of agricultural economy risk. Corresponding to a certain extent, it can also avoid the occurrence of credit risk of farmers. Throughout the country, the number of rural credit cooperatives in China is very large, dealing with credit risk is bound to need hardware and software and financial support. From the government point of view, national and regional governments should come up with supporting policies to provide big subsidy efforts for rural financial institutions and help to enhance the stability of rural credit and financial environment.

Basu P (2005) [29] conducts a survey using 6000 rural households in India and conducts an empirical analysis using the SHG Bank Linkage Model. Based on international experience, learning from micro-credit potential in India, he analyzes the government departments to pay attention to policy of this field, and proposes to expand the scale, and puts forward the way to provide funds for farmers. Based on empirical research on micro-credit in India, S Jha and KS Bawa (2007) [30] argues that the establishment of institutions, the diversification of knowledge and skills, the input of traditional and scientific knowledge and the sustainable protection of enterprises in rural areas can improve economic and environmental benefits.

From the questionnaire and survey data, based on model analysis, some domestic scholars propose credit risk settlement recommendations. According to the results of the model, find an obvious correlation between interest rate and default possibility of farmers, the significance level of the loans term is also very high. $\mathrm{He}$ believes that rural credit cooperatives should be appropriate to reduce the interest rate in providing loans to farmers and should extend the loan period. Liu Liyan (2013) [32] conducts an empirical study on rural credit cooperatives in Heilongiiang Province and 143 rural households. It is believed that they should focus on their per capita net income and asset value when providing loans to rural households, and takes these asset endowments as an important indicator when considering repayment possibility of farmers. At the same time, it is necessary to consider the age and the cultural level of the farmers who apply for loans, and rural credit cooperatives should control the amount of loans for older peasants whose cultural level is too low.

\section{Conclusions and discussions}

Based on the above research, the domestic and foreign scholars mainly analyze the risk factors and risk evaluation, including the qualitative analysis and the quantitative analysis. Qualitative analysis is putting forward the credit risk coping strategies from the macromanagement and institutional measures, quantitative analysis is studying credit assessment and impact factors of the credit risk from the construction of the model. At present, domestic scholars on credit risk research has taken shape. In the early stage, the theoretical analysis of credit risk of peasant households is more, the representative figures are Du Xiaoshan and so on. In the latter stage, the research on credit risk of rural households is mainly transferred to quantitative analysis. There are many types of measurement models, but there are few effective models for rural financial environment. And it is not enough in the index design, because the determination of index weight mainly comes from the subjective evaluation, such as qualitative score or expert judgment. The index design on the risk factor is still the difficulty of the current research. 


\section{Acknowledgements}

This research is supported by 2016 year Yunnan Philosophy and Social Science Planning Project (YB2016016), Scientific Research Foundation of Yunnan Provincial Education Department (2016ZZX080) and Doctor Research Foundation of Yunnan Normal University.

\section{References}

1. Huang J. On the Policy Effect and Risk Prevention of Farm Household Microcredit Loan. China Rural Finance, 2003 (12): 24-27.

2. Dai L.X., Li Z.H. and Yang F.W.Research on the Risks and Evaluation of Farm Household Microcredit Loan. Science and Technology, 2008,8 (3): 20-24.

3. Zhu X.L.Study on Risk Management of Rural Microcredit Loan. Economic Survey, 2010 (12): 80-83.

4. Tan Z.M. and Liang J.Operational Risks of Rural Microcredit Companies and Their Precautions - Based on the Survey and Analysis of Jiangsu Province. Rural Economy, 2011 (10): 51-53.

5. Duan W.J. An Empirical Analysis on the Risk and Benefit of Farm Household Microcredit Loan. Wuhan Finance, 2009 (1): 48-49.

6. Zeng Z.M. and Yue Y.D.Mechanism Innovation of Microcredit Credit Risk Management Based on Game Theory. Business Economics and Management, 2010 (8): 60-66.

7. Shi G.H., Pang Y. and Zhang Z.Y. A Stochastic Regulatory Game Analysis of Moral Risks of Farmers' Microcredit Loans. China Rural Survey, 2014 (6): 49-58.

8. Yang X.X., Xue R.X. and Ye H. Problems and Countermeasures of the Sustainable Development of Rural Credit Cooperatives Microfinance. Rural Economy, 2007 (5): 57-61.

9. Huang B.Y. On the Sustainable Development of Microfinance in Rural Credit Cooperatives. Economic Restructuring, 2008, 10 (2): 101-104.

10. Chavan P,Ramakumar R. Micro-credit andRural Poverty: An Analysis of Empirical Evidence. Economic and Political Weekly, 2002: 955-965.

11. Cipollini A,Fiordelisi F. Economic Value, Competition and Financial Distress in the European Bankingsystem. Journal of Banking \& Finance, 2012, 36

12. Jansson $\mathrm{K} \mathrm{H}$, Huisman $\mathrm{C} \mathrm{J}$, Lagerkvist $\mathrm{C} J$, et al. Agricultural Credit Market Institutions: A Comparison of Selected European Countries. 2013.

13. Li Z.B., Gao J.and Cui W.J. Study on Credit Risk Evaluation of Rural Credit Cooperatives. Journal of Beijing Electronics Science and Technology Institute, 2006, 14 (1): 69-74.

14. Wei L. Study on TheMicro Credit Risk Evaluation System of Peasant Household. Research on Finance and Economics, 2013 (8): 125-128.

15. Malik M, Thomas L C.Transition matrix modelsof consumer credit ratings. International Journal ofForecasting, 2012, 28 (1) : 261-272.
16. Awunyo-Vitor D, Mahama Al-Hassan R, Bruce Sarpong D, et al. Agricultural credit rationing in Ghana: what do formal lenders look for?.Agricultural Finance Review, 2014, 74(3): 364-378.

17. Hu Y., Xu H.L.and Wang X.Study on the Credit Rating of Micro-credit Loans for Farmers.Financial Theory and Practice, 2007, 28 (1): 30-33.

18. Nie Y. Study on the Performance Evaluation Model of Rural Microfinance Based on Multi Objective Decision Making. Journal of Huazhong Agricultural University (SOCIAL SCIENCE EDITION), 2009 (1): 6-9.

19. Wang J.and Zhu M.H. Study on Credit Risk Evaluation of Microfinance for Farmers Based on Catastrophe Theory.Financial Theory and Practice, 2011 (7): 20-23.

20. Yao S.Q.and Qiang J.H. Research on Credit Risk Assessment of Farmers' Microfinance Based on BP Neural Network. Journal of Northwest Sci-Tech University of Agriculture and Forestry (Social Science Edition), 2012, 12 (2): 78-83.

21. Hu H.Q., Zhang L.and Zhang D.H. Credit Risk Assessment Model of SMEs from the Perspective of Supply Chain Finance - A Comparative Study Based on SVM and BP Neural Network. Management Review, 2012,24 (11): 70-80

22. Peng M.D.and Cheng Y.Q. Finance Credit Evaluation Model of Peasant Household Micro Credit Based on Comprehensive Judgment Ability. Review of Management, 2015, 27 (6): 42-57.

23. Xiong X.P.and Yi F.H.Farmer Credit Risk of Rural Households: Performance, Causes and Countermeasures. East China Economic Management, 2005, 19 (11): 49-52.

24. Han X.P. andJin Y. Construction of Rural Credit Guarantee System in China. Journal of Agricultural Economics, 2014, 35 (3): 37-43.

25. Ding Y.H. Rural Microfinance Risk and Its Prevention. Rural Economy, 2006 (12): 67-69.

26. Yang H.L.and Xin R.Foundation of Micro-credit Risk Early-warning System in Peasant Households. Business Research, 2009 (6): 164-165.

27. Ma X.N.Research on the Micro-credit Risk Control Strategy of Rural Credit Cooperatives. Agricultural Economy, 2013 (7): 105-106.

28. Tong Y.B.and Qi W.N. Innovative Development and Sustainability of Microfinance in Rural Credit Cooperatives: A Case Study of Hainan. Agricultural Economics, 2014, 35 (5): 75-80.

29. Basu P, Srivastava P. Exploring Possibilities: Microfinance and Rural Credit Access for the Poor in India. Economic and Political Weekly, 2005: 1747-1756.

30. S Jha, K S Bawa. The Economic and Environmental Outcomes of Microfinance Projects: An Indian Case Study.Environment, Development and Sustainability,2007,(9): 229-239.

31. Li Z.B.and Gao J. Discriminant Analysis of Credit Risk of Rural Credit Cooperatives. Journal of Shandong Institute of Business and Technology, 2007, 21 (1): 76-82.

32. Liu L.Y.and Li X.G. Study on Factors Influencing Rural Household Credit Risk of Rural Credit Cooperatives: AAaseStudy of Heilongjiang Province. Anhui Agricultural Sciences, 2013, 41(13): 6023-6025. 